\section{Memes as Shortcut to Consumer Culture: A Methodological Approach to Covert Collective Ideologies}

\author{
Memes como um Atalho para a Cultura do Consumo: Uma Abordagem \\ Metodológica para Ideologias Coletivas Encobertas \\ Metodológica para ldeologias Coletivas Encobertas
}

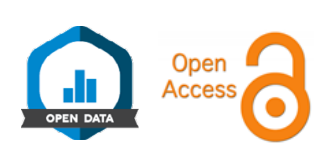

Elisa Priori de Deus*1 ${ }^{*}$

Roberta Dias Campos ${ }^{10}$

Ana Raquel Rocha ${ }^{1}$

\section{ABSTRACT}

Objective: the paper proposes the methodological use of memes as a shortcut to explore consumer culture. Memes as cultural texts can reveal collective circulating ideologies that may not be accessed through regular interviews. Context: memes are cultural texts that convey easy-to-understand messages, gaining strength within social networks. Cultural texts playfully present the social context and beliefs of societies. We analyzed circulating memes during the COVID-19 pandemic about elderly consumers in Brazil to outline a methodological protocol. Method: we analyzed memes adopting the discourse model to conduct qualitative research of memes as a shortcut to cultural discourses. We collected memes during March and May 2020 using social media networks. They were classified following thematic analysis. Result: the proposal is a methodological procedure for analyzing memes as a cultural text. The process starts with the outline of a data collection protocol, followed by data analysis guidelines, illustrated by the context of elderly consumers. Conclusion: the analysis of memes as cultural texts contributed to understanding of consumer behavior through current cultural content, revealing contrasting ideologies that emerge from consumers, as covert value-systems, circulating alongside institutional mass-mediated ideologies.

Keywords: memes; cultural text; consumer ideology; culture and consumption; qualitative research.

* Corresponding Author.

1. Universidade Federal do Rio de Janeiro, Instituto COPPEAD de Administração, Rio de Janeiro, RJ, Brazil.

Cite as: Deus, E. P., Campos, R. D., \& Rocha, A. R. (2022). Memes as shortcut to consumer culture: A methodological approach to covert collective ideologies. Revista de Administração Contemporânea, 26(4), e210005. https://doi.org/10.1590/1982-7849rac2022210005.en

Published as Early Access: January 05, 2022. Assigned to this issue: January $06,2022$.

\section{RESUMO}

Objetivo: o artigo propôe o uso metodológico de memes como um atalho para explorar a cultura de consumo. Os memes como textos culturais podem revelar ideologias circulantes coletivas que não podem ser acessadas por meio de entrevistas regulares. Contexto: memes são textos culturais que veiculam mensagens fáceis de entender, ganhando força nas redes sociais. Os textos culturais apresentam ludicamente o contexto social e as crenças sociais. Analisamos os memes circulantes durante a pandemia de COVID-19 sobre consumidores idosos no Brasil para traçar um protocolo metodológico. Método: adotamos o modelo de discurso para analisar os memes como uma pesquisa qualitativa de memes como um atalho para discursos culturais. Coletamos memes durante março e maio de 2020 usando as mídias sociais. Os memes foram classificados seguindo uma análise temática. Resultado: é uma proposta de procedimento metodológico para a análise dos memes como texto cultural. O processo inicia-se com o delineamento de um protocolo de coleta de dados, seguido de roteiro de análise de dados, ilustrado pelo contexto de consumidores idosos. Conclusáo: a análise dos memes como textos culturais contribuiu para compreensão do comportamento do consumidor por meio do conteúdo cultural atual, revelando ideologias encobertas, que emergem dos consumidores, como sistemas de valores velados que circulam em paralelo às ideologias institucionais de mídia de massa.

Palavras-chave: memes; textos culturais; ideologia de consumo; cultura e consumo; pesquisa qualitativa.
JEL Code: D4.

Editors-in-chief: Wesley Mendes-da-Silva (Fundação Getulio Vargas, EAESP, Brazil) (d) Marcelo de Souza Bispo (Universidade Federal da Paraíba, PPGA, Brazill) Guest Editors: Evelyn Lanka (Cranfield School of Management, United Kingdom) Sanjay Lanka (Fundação Getulio Vargas, EAESP, Brazil) Ali Rostron (University of Liverpool, United Kingdom) (C) Pallavi Singh (Sheffield Hallam University, United Kingdom) (C) Reviewers: Marlon Dalmoro (Universidade do Vale do Taquari, Brazil) $\mathbb{C}$ Two reviewers chose not to disclose their identities. Peer Review Report: The disclosure of the Peer Review Report was not authorized by its reviewers.

Received: January 14, 2021 Last version received: October 29, 202 Accepted: November 22, 2021

\begin{tabular}{|c|c|c|c|c|c|c|c|c|c|}
\hline & 1 & 2 & 3 & 4 & 5 & 6 & 7 & 8 & 9 \\
\hline $1^{\text {st }}$ round & $\stackrel{D}{2}$ & $x$ & $x$ & $\stackrel{0}{2}$ & & & & & \\
\hline $2^{\text {nd }}$ round & $\stackrel{9}{\circ}$ & $x$ & (x) & (x) & $\varphi$ & & & & \\
\hline
\end{tabular}




\section{INTRODUCTION}

In 2020, a new trending topic emerged on the internet. Artists and anonymous people worldwide, through their own-crafted photomontages, joined the challenge of summarizing the coronavirus-fighting quarantine and the year of 2020. Memes had the same structure on everyone's expression: authors were supposed to express their moods throughout the 2020 year, from January to September (GShow, 2020). The challenge created a global echo around the COVID-19 confinement experience.

Social media has become an arena for collective debate on pandemic experiences, and memes have become an essential digital tool to convey messages, criticism, or share feelings and experiences (Anapol, 2020). Memes are easy-to-understand messages, resulting from the adaptation of real-life topics attractively depicted that spread like a digital entertainment piece (Davison, 2009). Miller et al. (2020) claim that memes are also used as moderators of values and morality, turning a piece of entertainment into a covert public debate of current topics.

Scholarship explored different forms of cultural texts, such as reality shows (Campos, 2009), TV series (Suarez, Motta, \& Barros, 2009), soap operas (Faria \& Casotti, 2014), films (Abreu \& Casotti, 2018), lyrics songs (Askegaard, 2010), advertising (Thompson, 2004), or news (Humphreys, 2010). Cultural texts, in general, playfully represent beliefs, contexts, rules, and principles that guide societies (Hirschman \& Stern, 1994), but they also represent consumers' interpretive strategies to deal with dominant ideologies (Arnould \& Thompson, 2005). In our view, memes have a methodological potential as cultural texts that can reveal collective circulating behaviors and ideologies.

This paper's objective is to show the methodological potentials of memes as a specific cultural text, which can be used to investigate consumer culture. We propose to methodologically explore new cultural texts such as memes that have been gaining traction in contemporary culture and still have an underexplored potential as a method to access ideologies and consumer interpretative strategies (Miller et al., 2019). Memes expose ephemeral cultural values focusing on meanings ascribed to cultural patterns at a particular time, which can be different mainstream values. They as cultural texts may favor different entries to such interacting ideologies. Furthermore, memes are an opportunity for research of digital cultural texts, particularly those crafted by consumers.

The investigation of memes presents methodological challenges that have to be addressed by specifically tailored strategies, which are the main contribution of this article. Because of this, we conducted empirical research to explore the potential difficulties of employing memes as a methodological source, and to craft protocols and procedures for data collection and analysis. We analyzed memes that were considered trendy during the COVID-19 pandemic, more particularly regarding elderly consumers, exploring the potential of such cultural text as shortcuts for contemporary sensibilities.

First, since memes are not publicly displayed, data collection depended on the researcher's social media contacts and networks. The memes demand strategies to guarantee a broad reach of data while compensating bias for convenience sampling. Next, inspired by the thematic analysis tenets (Braun \& Clarke, 2006), we designed a four-step approach to analyze memes that encompass (a) funneling the collected data into a final data set, (b) coding the memes, (c) identifying themes, and (d) identifying global themes that depict underlying ideologies.

The article is organized as follows. Next section, we provide the theoretical background on memes as cultural expression of culture and the role of cultural texts in researching consumer culture. Next, we present the methodological procedures to explore the memes as methodological resources. Subsequently we offer an illustration of analytical procedures with the context of elderly consumers during the COVID-19 pandemic. Finally, we discuss the potential contribution of the method, contrasting with existing cultural texts already present in the literature. The paper ends highlighting the paths for further studies.

\section{MEMES AS CULTURAL EXPRESSION OF CONSUMPTION CULTURE}

Internet memes are a cultural expression, commonly formulated in the form of jokes or criticism that become relevant through exchanges on the internet in different formats: static, animated gif, or video (Davison, 2009). They are a kind of visual amusement with simple images that do not pretend to be necessarily beautiful or realistic but to entertain and transmit a specific message (Börzsei, 2013).

The term meme itself comes from biology, where memes are defined as processes of imitation that enable the evolution of species. Dawkins (1976) states that genes with a greater capacity to imitate others' behavior will survive and guarantee the evolution of species. Anthropology, sociology, and psychology used the term (related to imitation) to explain societies' social and cultural development (Blackmore, 2000; Börzsei, 2013). Blackmore (2000) use Dawkins' theory to claim that culture is a construction that depends on imitating human behavior to perpetuate. 
Imitations accepted throughout time have remained and defined adjacent societies' behavior.

The advent of the internet expanded the usage of the term to explain content disseminated among users. Memes are messages portrayed by image and text, in a limited space, created out of trend topics, such as celebrity gaffes, political themes, cinema items, and different behaviors (Börzsei, 2013). Davison (2009) indicates that memes are composed of three aspects: the manifestation of the phenomenon, behavior undertaken in meme production, and the ideal message transmitted.

The manifestation relates to external observable phenomena portrayed in the meme, displayed through images and texts. The behavior has to do with the activities undertaken to create the meme, such as taking pictures, drawing something, or writing sentences to be used in meme production. In turn, the ideal message corresponds to the core message the meme transmits.

It is characteristic of memes to understand and display straightforward texts and images that generate quick spread. However, the combination of image and text is not a rule. If one of these elements is intelligent, funny, or shocking enough, it can stand alone. Nevertheless, the focus is on making the text striking about what images are showing (Miller et al., 2020). Miller (2020) attributes to memes a particular way of guarding morality, saying which behaviors are most appropriate at that moment and for which group the messages are targeted. Rapid dissemination and ease of understanding contribute to creating a 'moral consensus' shared among people on social media.

Memes express the present from a cultural perspective (Davison, 2009). We note that endless meaningful memes tend to be rare. They expose ephemeral cultural values focusing on meanings ascribed to cultural patterns at a particular time. Memes are a recent cultural manifestation, which somehow justifies the scant literature about this phenomenon in direct marketing and consumer behavior journals. In some studies, memes are mainly presented as examples, without the intention to explain them (Gannon \& Prothero, 2016; Luedicke, Thompson, \& Giesler, 2010; McDonald \& Dan, 2020).

Borgerson and Miller (2016) intended to explain what memes are and to list their related meanings. Nevertheless, none of these studies explores memes as a cultural text that reveals values, beliefs, and contexts (Hirschman \& Stern, 1994). Meme's analysis provides an opportunity for marketing and consumer behavior researchers to look closer at a phenomenon of high currency.

\section{CULTURAL TEXTS AS A RESOURCE FOR CONSUMER RESEARCH}

Cultural texts have been a valuable resource for the research in marketing and consumer research (Hirschman, 1988; 2000; Suarez, Motta, \& Barros, 2009) for they offer both researchers and professionals a glimpse into consumer culture. They are aired through mass-mediated programs, such as soap operas, films, advertisements, and marketing campaigns (Hirschman, 1988) and they depict circulating values, beliefs, and ideologies. Through intertextuality between several cultural texts, consumers connect their behaviors with collective narratives, values, and mainstream ideologies (Hirschman, 2000). Cultural texts also express how consumer's ideologies circulate (Cova \& Cova, 2009). These ideologies represent social circulating values at a particular time, and with time, ideologies are revised and reinvented (Holt, 2003).

We identified different formats of cultural texts that are produced by mass media (such as soap opera and reality shows), by advertising agencies and marketing departments (TV or print advertising), by journalism institutions (newspaper articles or TV news), or cultural industry (song lyrics, films, and music shows). They present different angles of social circulating ideologies, associated with varied authorships and value systems.

Films and documentaries, for instance, transform complex themes into easy-to-understand scenes, and they explore present consumption paths and practices in the natural environment (Abreu \& Casotti, 2020; Tadajewski \& Hamilton, 2014). Tadajewski and Hamilton (2014) analyzed two documentaries on post-consumer waste. The texts reveal the need for marketing to pay attention to "the moral and ethical implications of our consumption choices" (Tadajewski \& Hamilton, 2014, p. 81). Abreu and Casotti (2020) analyze the content of four films about transformative experiences in the context of elderly consumers. The films show how transformative experiences, such as travel, can influence the transformation of consumers' identities.

Advertising is another form of cultural text that provides access to marketplace ideologies or mythologies. Thompson (2004) analyzed advertisements published in Natural Health magazine between 1998 and 2007. Advertising discourse provides a symbolic environment to frame consumers' beliefs on products' efficiency to the point of changing their lifestyle. Consumers end up incorporating advertising discourses into their own and defend the use of such techniques (Thompson, 2004). Another article explored female beauty advertising to identify whether the marketing discourse reflects the desires and values of consumers. The study revealed that advertising discourse 
does not reverberate consumer values about female beauty (Goia, Lima, \& Barros, 2018).

Journalism is an important author of cultural texts. Newspapers and TV news reach a vast number of people in a narrative that strives for neutrality and objectivity. Humphreys studies the legitimation process in newspapers (Humphreys, 2010; Humphreys \& Latour, 2013). Her first study investigated the legitimation of casinos by analyzing the journalistic content around the topic. The publications contributed to legitimize and legalize casinos in several American states (Humphreys, 2010). Humphreys and Latour comparatively analyzed the role of newspapers' discourse to legitimize the consumer's perception of gambling. Authors identified that cultural texts could guide legitimacy among consumers who oppose this practice (Humphreys \& Latour, 2013).

Music can reveal the consumption of aesthetic products like the kind of music dominated in a specific time. However, the lyrics of songs, in particular, are able to understand the past consumer behavior (Askegaard, 2010). Askegaard (2010) historically analyzed 18 lyrics of the Beach Boys released between October 1962 and July 1964 to understand the "developing and disseminating [of] a mythology of white, middle-class California lifestyles" (Askegaard, 2010, p. 351). Holbrook (2008) examined the plots of three crime-plus-jazz motion-picture genre films, from different periods: 1955, 1984, and 1996. Holbrook (2008) understood the "meanings of cine musical performances as these illuminate the contrast or conflict between commerce (crime) and art (jazz)" (Holbrook, 2008, p. 308).

Soap operas, TV series, and TV shows are massmediated programs, normally targeted for all classes. These formats contribute to building the identity of consumers, and their consumption paths are discussed and spread by the media (Faria \& Casotti, 2014; Ramos, Tayt-Son, \& Rocha, 2020). Campos (2009) analyzed the reality show America's Next Top Model, along with the Brazilian version of the show. She collected key scenes of the contest, along with an analysis of editing choices. Suarez, Motta, and Barros (2009) investigated the TV series called A Diarista that depicts the daily life of a cleaning lady from popular classes. Both texts romanticize and simplify cultural realities defined by strong cultural norms such as standards of beauty or the stigma surrounding the popular consumer. Faria and Casotti (2014) claim that cultural texts have shown that soap operas reflect the invisibility of people with disabilities and often the exclusion of these consumers in society by institutions, the market, and other consumers.

Books are cultural texts as well. Brownlie and Hewer (2007) analyzed the content of the images printed in one of Jamie Oliver's cookbooks, The Return of the Naked Chef (2001). The authors found a change in the ideologies that build male gender identity by exploring photos with men in the kitchen, an environment often considered by mainstream gender ideologies as feminine.

All these cultural texts researched were created by institutional authors - the market, journalism corporations, mass-media channels, or mass media. They represent institutional ideologies that reshape, influence, or depict consumer culture. Each text offers an angle of ideology production and circulation, highlighting arenas more or less institutionalized, with different intentions toward society. Table 1 reproduces a summary of the differences of the cultural texts present in consumer behavior and marketing literature.

Table 1. Types of cultural texts as shortcuts to analyze ideologies.

\begin{tabular}{|c|c|c|c|c|c|}
\hline $\begin{array}{c}\text { Type of cultural } \\
\text { text }\end{array}$ & Authorship & Methodology & Analytical procedures & Theoretical contributions & Articles \\
\hline Soap opera & Mass media & Qualitative & History, practices, and texts & $\begin{array}{l}\text { Representations and } \\
\text { stereotypes }\end{array}$ & Faria and Casotti (2014) \\
\hline \multirow{3}{*}{ Advertising } & \multirow{3}{*}{$\begin{array}{l}\text { Advertising } \\
\text { agencies; } \\
\text { marketing } \\
\text { departments }\end{array}$} & \multirow{3}{*}{ Qualitative } & Archetypes & Marketplace mythologies & Thompson (2004) \\
\hline & & & Content analysis & $\begin{array}{l}\text { Consumption, marketing } \\
\text { agents' practices, and the } \\
\text { industry field }\end{array}$ & $\begin{array}{l}\text { Goia, Lima, and Barros } \\
\text { (2018) }\end{array}$ \\
\hline & & & $\begin{array}{l}\text { Longitudinal social semiotic } \\
\text { analysis }\end{array}$ & $\begin{array}{l}\text { Consumption, marketing } \\
\text { agents' practices, and the } \\
\text { industry field }\end{array}$ & Freeman and Bell (2013) \\
\hline \multirow[b]{2}{*}{ News } & \multirow{2}{*}{$\begin{array}{l}\text { Newspapers and } \\
\text { televisions }\end{array}$} & \multirow{2}{*}{$\begin{array}{l}\text { Quantitative } \\
\text { content } \\
\text { analysis }\end{array}$} & \multirow[b]{2}{*}{ Discourse analysis } & \multirow{2}{*}{$\begin{array}{l}\text { Institutional legitimation } \\
\text { as a historical process }\end{array}$} & Humphreys (2010) \\
\hline & & & & & $\begin{array}{c}\text { Humphreys and Latour } \\
\text { (2013) }\end{array}$ \\
\hline
\end{tabular}


Table 1. Types of cultural texts as shortcuts to analyze ideologies (Continued).

\begin{tabular}{|c|c|c|c|c|c|}
\hline $\begin{array}{c}\text { Type of cultural } \\
\text { text }\end{array}$ & Authorship & Methodology & Analytical procedures & Theoretical contributions & Articles \\
\hline \multirow{4}{*}{$\begin{array}{l}\text { Fiction content } \\
\text { produced by TV }\end{array}$} & \multirow{4}{*}{ Mass media } & \multirow{4}{*}{ Qualitative } & History, practices, and texts & $\begin{array}{l}\text { Intertextuality and } \\
\text { archetypes }\end{array}$ & Hirschman (2000) \\
\hline & & & History, practices, and texts & $\begin{array}{l}\text { Drawing of a structuring } \\
\text { symbolic system }\end{array}$ & Campos (2009) \\
\hline & & & Narrative syntactic analysis & $\begin{array}{c}\text { Representation of the lower } \\
\text { classes }\end{array}$ & $\begin{array}{l}\text { Suarez, Motta, and Barros } \\
\text { (2009) }\end{array}$ \\
\hline & & & Narrative syntactic analysis & $\begin{array}{l}\text { Reframing a consumption } \\
\text { practice }\end{array}$ & $\begin{array}{l}\text { Ramos, Tayt-son, and } \\
\text { Rocha }(2020)\end{array}$ \\
\hline \multirow[t]{2}{*}{ Music } & \multirow[t]{2}{*}{ Music industry } & \multirow[t]{2}{*}{ Qualitative } & $\begin{array}{l}\text { Analysis of historical consumer } \\
\text { cultural product }\end{array}$ & $\begin{array}{l}\text { Consumer subcultural } \\
\text { systems }\end{array}$ & Askegaard (2010) \\
\hline & & & Analysis of cinemusically & Symbolic consumption & Holbrook (2008) \\
\hline \multirow{2}{*}{ Book } & \multirow{2}{*}{ Literary industry } & \multirow{2}{*}{ Qualitative } & $\begin{array}{l}\text { Analysis of visual narrative } \\
\text { content }\end{array}$ & $\begin{array}{l}\text { Construction of a gender's } \\
\text { identity }\end{array}$ & $\begin{array}{l}\text { Brownlie and Hewer } \\
\text { (2007) }\end{array}$ \\
\hline & & & Textual analysis & $\begin{array}{c}\text { Contemporary consumer } \\
\text { culture }\end{array}$ & $\begin{array}{c}\text { Brownlie, Hewer, and } \\
\text { Horne (2005) }\end{array}$ \\
\hline \multirow{3}{*}{ Films } & \multirow{3}{*}{ Film industry } & \multirow{3}{*}{ Qualitative } & $\begin{array}{l}\text { Content analysis - lines and } \\
\text { contexts of the characters }\end{array}$ & Transforming experiences & Abreu and Casotti (2020) \\
\hline & & & Inductive analysis & Anthropomorphic & $\begin{array}{l}\text { Lanier, Rader, and Fowler } \\
\text { (2013) }\end{array}$ \\
\hline & & & Content analysis & Ethical consumption & $\begin{array}{c}\text { Tadajewski and Hamilton } \\
(2014)\end{array}$ \\
\hline
\end{tabular}

Note. Source: Elaborated by the authors.

Previous studies show that cultural texts diffuse value systems that do not necessarily correspond to the ones consumers internalize (Goia, Lima, \& Barros, 2018; Thompson, 2004). Moreover, often they work to reshape or influence consumers' perspectives (Humphreys, 2010; Humphreys \& Latour, 2013). Cultural narratives are a heterogeneous domain that demands more complex and sophisticated forms of research. The strategy behind the methodological choice of cultural texts may favor different entries to such interacting ideologies. Besides, there is an opportunity for more research of digital cultural texts, particularly those that are crafted by consumers. Memes, like other cultural texts, can reveal the ideology present in digital environments, achieving a large audience through the circulation from peer-to-peer interaction. In the next section, we present the methodological procedures to research the memes as a cultural text.

\section{MEMES AS A RESEARCH SOURCE OF CONSUMER CULTURE: METHODOLOGICAL PROCEDURES}

Memes are a type of cultural text underused so far. We advocate that this cultural text might reveal subjacent aspects of consumption that would be hard to identify through other qualitative sources. It is a short textual and visual manifestation, carrying a clear intention of message propagation, related, predominantly, to current themes, values, beliefs, and ideologies. Memes are imbued by consumer's experience since only those with good transitioning life repertoire may understand their message. Still, even if memes are consumed individually, their circulation promotes group recognition, at least among those who can decode the core message. However, such an investigation faces particular challenges that have been addressed in this research by specifically tailored strategies.

\section{Methodological toolbox to research memes}

We discuss the methodological strategies to perform research around memes. We depart from a model of discourse (Hirschman, Scott, \& Wells, 1998) and add thematic analyses to the process (Braun \& Clarke, 2006), promoting necessary methodological adaptations of both methods to analyze the memes.

The discourse model is a seminal article in the proposition of using cultural texts as data. It follows a 
particular framing of consumption, focusing on products and services. And it also defends the triangulation of cultural texts with historical texts for a broader account of the construction of meanings underpinning the consumption practice under scrutiny.

However, several authors, even if inspired by the tenets of Hirschman, Scott, and Wells (1998), adapted their protocols to meet the demands of their research objectives. Campos (2009) and Faria and Casotti (2014), for instance, revised their framing strategy to encompass topics related to consumption across several categories, such as beauty or stigma. Authors chose to pursue their analysis without contrasting cultural texts with historical data or consumer interviews (Abreu \& Casotti, 2018; Campos, 2009; Faria \& Casotti, 2014; Suarez et al., 2009).

Beyond the theoretical support provided by Hirschman et al. (1998), we followed the thematic analysis (Braun \& Clarke, 2006) to structure the analytical procedures proposed to address memes. Thematic analysis (Braun \& Clarke, 2006) is a foundational method that guides a rigorous yet flexible analytical process, coupled with different analytical strategies that researchers may choose to employ. This method enables researchers to demonstrate, step by step, all decisions they made since initial coding until the moment when the proposed global themes are reached.

\section{Collecting and organizing memes for analysis}

Data collection was the first challenge in methodological design and was crafted to obtain a diversified sample of memes through the engagement with researchers' digital networks. Memes are not like a film or soap opera where you can take the samples on TV, cinema, or the internet. Researchers need to involve their networks like relatives, friends, coworkers, or even employ professional recruitment services to receive a wide set of memes. Further, the content of memes is fast and fleeting (Miller et al., 2020), which is a preponderant theme today, for a meme can be replaced quickly by another one. Data collection must be agile and account for the moment where memes appear in the networks.

Once data collection is over, authors performed a procedure identified as funneling, when, after the first contact with the total raw corpus of data amassed, researchers classified memes attuned. Thus, funneling demands a definition of critical topics that will guide the researcher's judgment throughout meme sorting, separating the ones that are relevant for the research from those that do not seem connected. This procedure will provide what we will reference, from now on, as the final data set, i.e., the set of memes that will be the basis of procedures of coding and analysis.

Since this procedure relies heavily on the researcher's judgment, it is essential to establish parameters to guide such classification. In the thematic analysis method, the construction of themes can be both inductive and theoretical. In the inductive process, it is possible to code directly from data, whereas in the theoretical process, it is possible to code from theory that underlies the research as a whole (Braun \& Clarke, 2006). The analyses of themes can also occur in semantic or latent levels (Braun \& Clarke, 2006). In semantic analysis, researchers focus on what is said literally by participants, on explicit meanings. On the other hand, in latent analysis, researchers explore underlying meanings, ideologies, and concepts that may shape semantic content (Braun \& Clarke, 2006).

\section{Coding and analysis of memes}

Braun and Clarke (2006) inspired a step-by-step path that we propose to guarantee a thorough coding process that also identifies global ideologies present in cultural texts. The analysis of memes followed three main analytical procedures: (a) data coding generation; (b) search, definition, and naming of context-related themes across memes; and (c) identification of global themes, with the deep description of underlying values.

Coding started with the familiarization with data, which consists of an attentive reading searching for meanings and patterns. Next, researchers initiated the generation of codes. A code is a short word or phrase that captures the essence of what the data shows (Braun \& Clarke, 2006; Saldaña, 2009). Following Braun and Clarke (2006), at this stage, coding followed terms or expressions toward the core message of the cultural text, crafting an emergent inductive or/and theoretical map of codes out of the final data set.

Lanka, Topakas, and Patterson (2020) contribute to a thematic analysis by proposing a hierarchy among themes, differentiating from initial sub-themes to second-order, broader, and more abstract themes. The latter, related to the context, are named 'themes,' and the former, related to ethics and underlying conceptual values, are named 'global themes.' Thus, in the next phase, researchers analyzed the themes to refine their findings into global themes that describe underlying ideologies and value systems (Lanka, Topakas, \& Patterson, 2020). Global themes, then, refer to broader and more conceptual topics that symbolically structure the narrative of the cultural texts analyzed.

The following section will present an illustration of the method and challenges related to its application. 


\section{ILLUSTRATING A RESEARCH WITH MEMES: ELDERLY CONSUMERS DURING THE COVID-19 PANDEMIC}

We illustrate the use of memes as methodological sources in the context of elderly consumers during the pandemic of COVID-19. Consumers older than 60 years old are considered a significant risk group for COVID-19 and, therefore, were placed in the spotlight in 2020. Brazil has about 28 million people over 60 years old, representing $13 \%$ of the population (Perissé \& Marli, 2019). The elderly are also the providers for $19.3 \%$ households in Brazil (Neri, 2020). However, old age in Brazil faces the barriers of prejudice and stigma, inhabiting a country that praises youth (Rodrigues \& Soares, 2006).

\section{Collecting and organizing memes for analysis}

In this research, memes were not publicly displayed, and therefore they were obtained through a snowball-like approach (Malhotra, Hall, Shaw, \& Oppenheim, 2008). For two months, the first and second authors engaged their network and invited other researchers, with different ages and social profiles, to provide memes from their own WhatsApp networks. Mobilizing the network involved several steps to energize those engaged in providing memes: (a) initial invitation to contribute to the research, (b) 'thank you' messages for every meme received reinforcing the value of the contribution, and (c) regular notifications informing contributors that the research was still on.
The collection began on March 26, 2020, thirteen days after WHO declared the pandemic and after the closure of schools, commerce, and industries in Brazil by governmental decrees. Data collection occurred from $03 / 26 / 20$ to $05 / 25 / 20$. Researchers gathered 646 memes of the most diverse themes related to the pandemic. The team explored the material collected and discarded memes unrelated to consumption, resulting in 442 memes. A closer look at finding elderly memes led to a final set of 25 memes to be analyzed.

To define elders, we followed the criteria established by the literature (Debert, 2000; Goldenberg, 2011; Lee, Carpenter, \& Meyers, 2007; Rosenthal, Cardoso, \& Abdalla, 2021): people that looked aged 60 or over. Physical characteristics of aging and artifacts guided the classification of images: white hair, wrinkles, and the use of accessories as cane and glasses. In addition, words in the texts, commonly attributed to elderly, such as 'old' or 'coroa' (elder), were considered by the researchers.

Memes featuring elderly in the pandemic had greater volume within the first two months of the pandemic, after which other relevant topics replaced them. Figure 1 shows that we identified 12 memes in the first five days of collection. This time is proportionally more expressive than the number of memes we gathered in the subsequent periods (April, 30 days, ten memes, and May, 25 days, three memes). This suggests that after the first two months of the pandemic, the elderly's vulnerable condition had gradually lost prominence. The loss of relevance of memes about elderly consumers in the COVID-19 pandemic is due to a characteristic of memes expressing ephemeral cultural patterns for a short time (Davison, 2009). This also indicated data collection was over and helped us define a definitive sample collection.

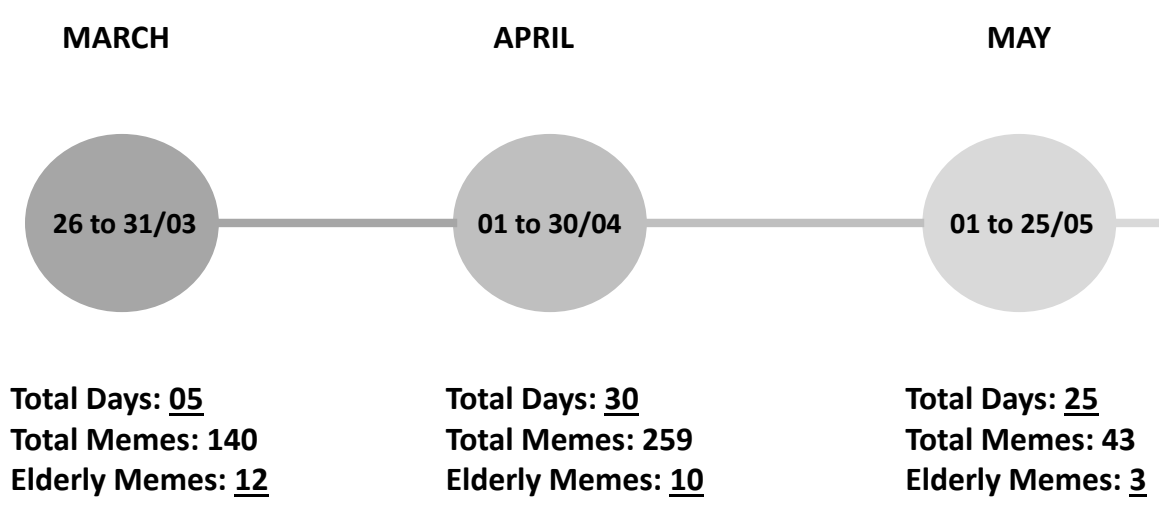

Figure 1. Elderly meme timeline.

Source: Elaborated by the authors. 


\section{Coding and analysis of memes}

The thematic analysis helped us outline the procedures taken on converting raw data into themes. We adopted both patterns in this work: inductive codes emerged from memes themselves, and theoretical codes were employed, following Lee, Carpenter, and Meyers (2007) and Rosenthal, Cardoso, and Abdalla (2021). We also performed a latent analysis of the content of memes to capture cultural values of a given moment.

Coding was initiated by the first author, and then presented to second and third authors and three external reviewers for feedback and improvement. The 25 memes resulted in a table with 53 (Appendix 1 in the shared dataset) different inductive and theoretical codes. We observed that, in some cases, one meme was connected to more than one code.

The coding process was stored in an Excel sheet to create a map of memes, indicating pervasive characteristics in the final data set. This step offered a first overview that must be followed by a deeper and more descriptive account of codes that will ground the identification of themes. The codes sometimes overlapped so that the themes could reflect the phenomenon investigated as a whole. In our data set, elderly consumers are more frequently depicted as women $(65 \%)$ and in subordinated metaphoric roles, like children $(42 \%)$, pets $(11.5 \%)$, or teenagers $(34.6 \%)$. In a few cases, the elderly are in the position of adults (30\%). Most of the memes follow an ironic tone of voice (73\%), to subtly indicate to the elderly that they are part of a risk group $(30.8 \%)$ or that they should submit to family protocols
(61.5\%). Most memes refer to older people (69\%) instead of having the elder as the main narrator of the message (23\%). In these few instances, the elderly is venting about delaying life enjoyment or the fear of contamination and death.

In the sequence, the researchers were concerned to find conceptual themes across the 53 codes. Themes identify patterns in the organized data and develop in details that give meaning to the phenomena (Braun \& Clarke, 2006; Saldaña, 2009). The identified themes represented different aspects concerning elderly consumers and the COVID-19 pandemic. The research team carried out a new evaluation of the codes and agreed with the creation of three themes that illustrated emergent dynamics from the coding process, reflecting what codes revealed about elderly consumers in Brazil during the COVID-19 pandemic.

The final themes are: ambiguous boundaries of elderly condition, surveillance over elderly, the elderly experience. In this particular project, the resulting global theme authority under contest - highlights underlying symbolic aspects of the elder condition, not related to the specific context of the pandemic (Lanka et al., 2020).

Briefly, the complete analysis of data covered four main steps (Figure 2): familiarizing with data and funneling (from 442 to 25 memes), initial coding (53 codes), identification of themes across memes, and identification of a global theme across themes. The process covered steps from broadening data exploration through the open coding process to focusing on the underlying central axis that structures the phenomena under study.

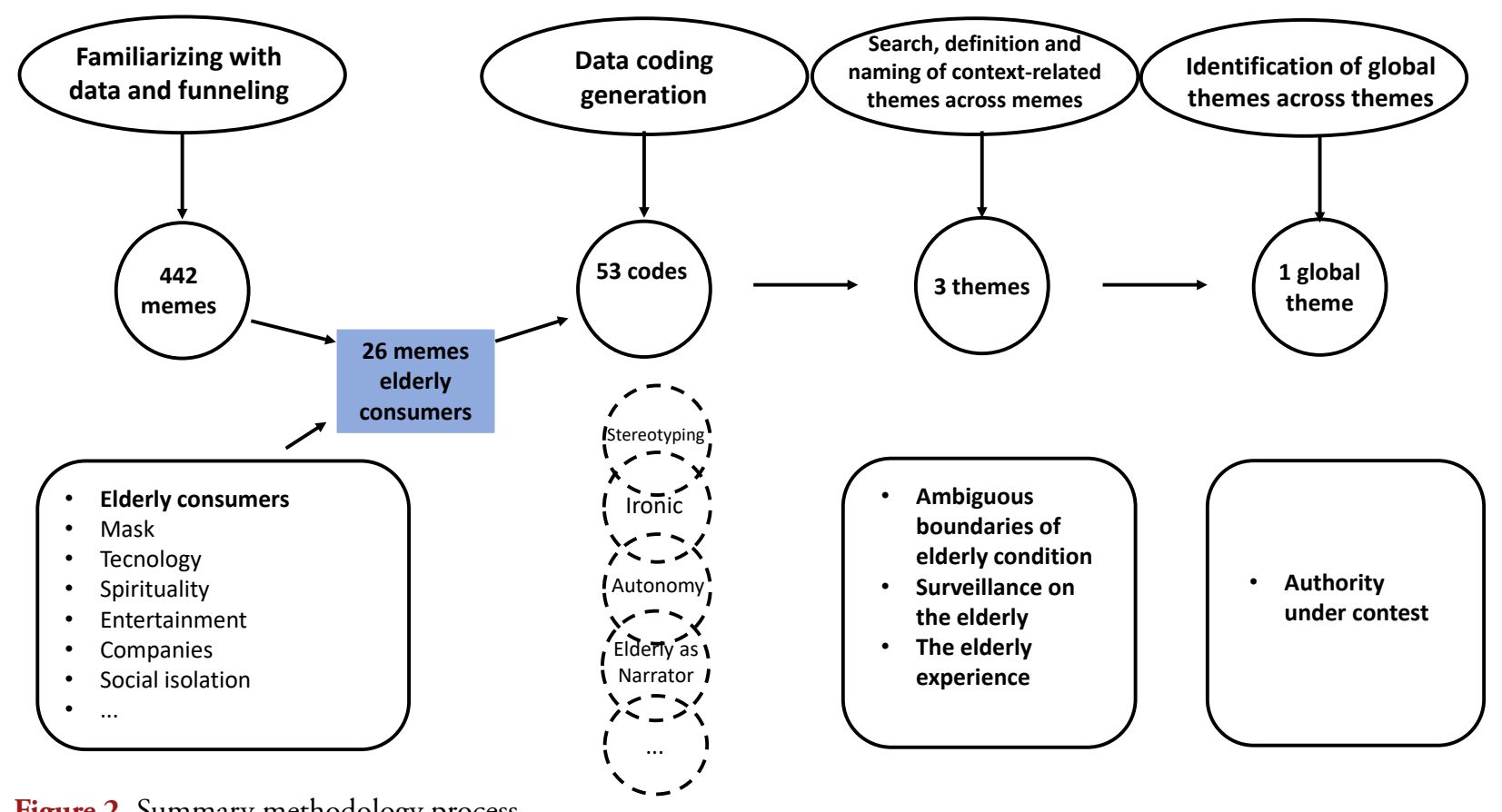

Figure 2. Summary methodology process.

Source: Elaborated by the authors. 


\section{Illustration of the four themes}

In the following paragraphs, we will provide an illustration of the four themes and the global themes, to illustrate how the analysis of memes resulted in a more conceptual understanding of underlying value systems conveyed by memes.

\section{Theme 1: Ambiguous boundaries of elderly condition}

Debert (2000) recalls that transitioning from a product to a non-productive adulthood has become somehow imprecise. Structural changes in the aging process of people have led to healthier and more independent older people. Thus, the definition of elderly gains other layers than just chronological ones. Consequently, the definition of a COVID-19 risk group inherits such ambiguous boundaries. Some memes refer to this ambiguity when it comes to identifying members of the risk group. The first group of memes recurs to objects as markers of a moment in the past in a playful way.

The first meme shows a telephone coin, and the image of the Guri de Uruguaiana, a local southern Brazilian character. The sentence states: "If you remember what this is for, don't leave home... like me, you belong to the risk group." The phone coins were created in the 1960s by the Brazilian Telephone Company (CTB) to use on public telephones. Both objects remained in use in Brazil until the 1990s when CTB created phone cards (Reis, 2013). Through objects of past generations, the memes stereotyped the elderly and offered a way out to the social embarrassment related to reference aging in Brazil. The memes using the objects offer an ironic and clever solution for the elders to self-identify as a risk group.

Meme 2 shows the frog Kermit, a character of The Muppets Show, lying on a bed and expressing his sadness: "When we think we have reached the best age, the world takes a turn and we become a risk group." Kermit is one of the oldest muppets created by Jim Henson. He made his debut on the Sesame Street TV show in 1969 (AdoroCinema, 2020). Kermit performed the elder as the narrator of his own story. Humor is present in the narrative but, unlike other memes of the group, in an empathic mood, demonstrating the frustration of the elderly with the situation. Ideally, Kermit exposes the feelings of the 21st century elderly who took care of their body and mind and lived under balanced financial conditions to take care of themselves and carry out their projects (Rodrigues \& Soares, 2006), but the Covid-19 pandemic imposed an unexpected vulnerability on the elderly.

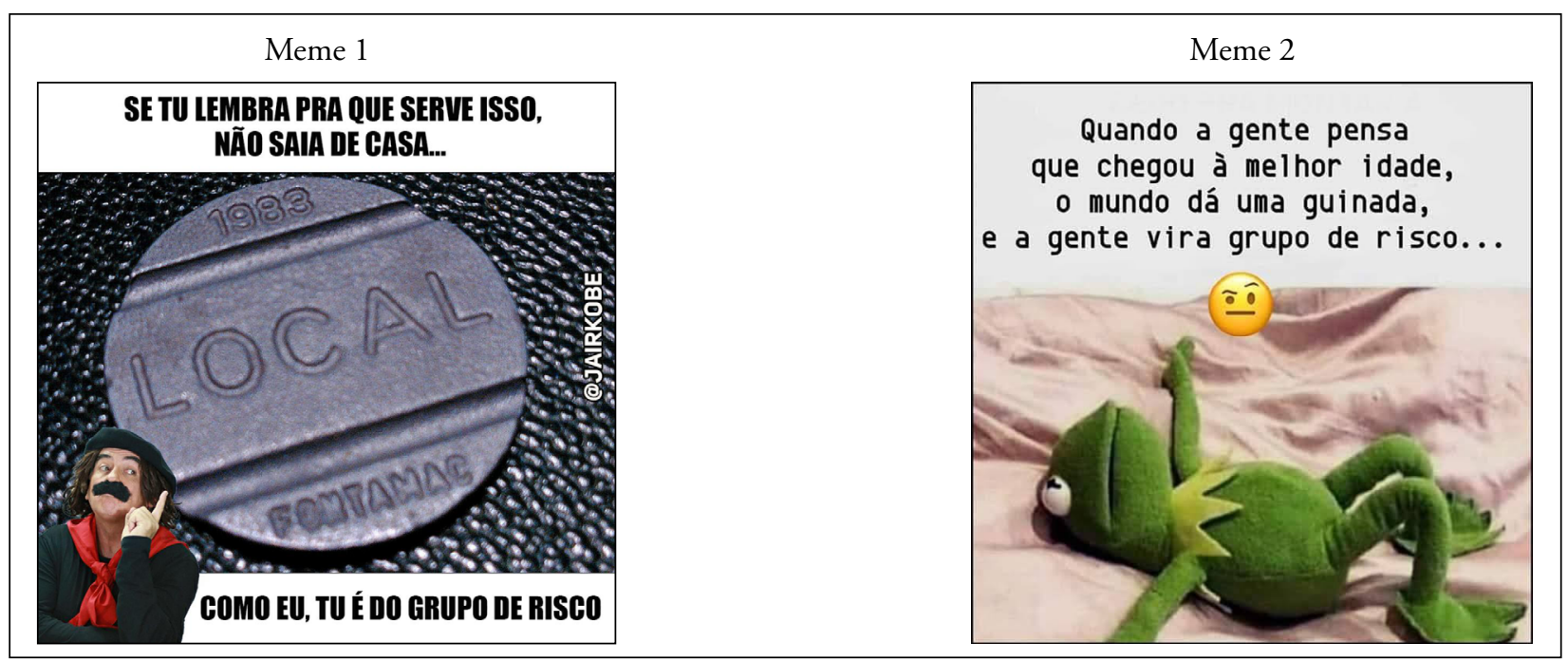

Figure 3. Ambiguous boundaries of elderly condition.

Source: Elaborated by the authors.

\section{Theme 2: Surveillance on the elderly}

Surveillance is a shadow over elderly consumers who are monitored constantly by the family or society. Two groups of memes highlight this issue. The first of them calls attention to a society that monitors people's behavior and tells the elderly that the ideal behavior for this group is to stay at home (memes 3 and 4), what Miller et al. (2020) state, that memes are regulators of human behavior, indicating what should or should not be done. 


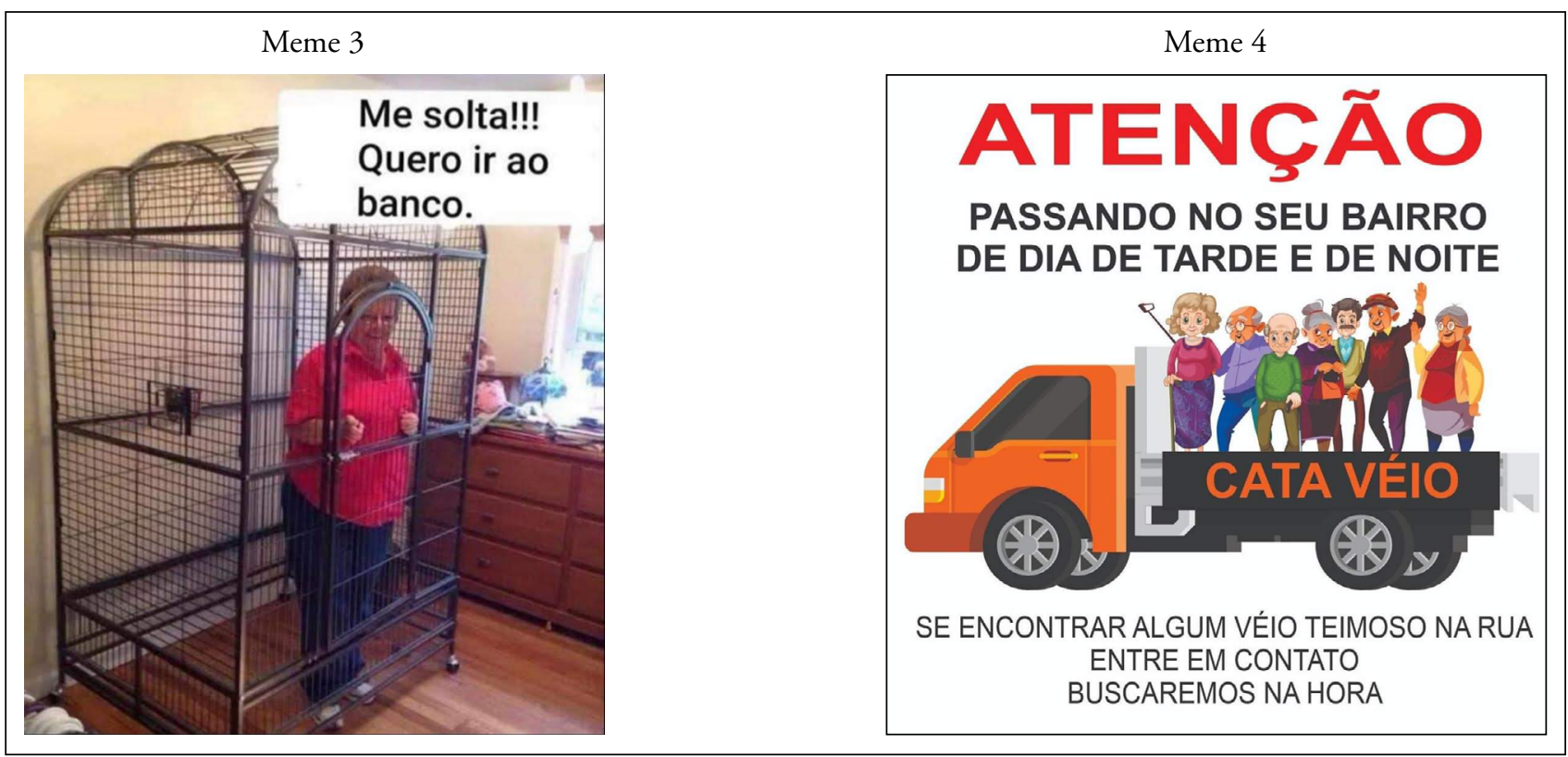

Figure 4. Surveillance on the elderly.

Source: Elaborated by the authors.

Meme 3 shows an older woman trapped in a cage, holding the cage door in an attempt to break free. She says: "Release me! I want to go to the bank." In this meme, the elderly person narrates the experience, although she is not responsible for the experience itself since someone put her in the cage. It suggests that a family member watches over her steps, as if it is the role of the family to control the elderly, assuming that they are not able to do it by themselves (Debert, 2000).

Meme 4 indicates that surveillance transcends family boundaries and becomes performed by society. Memes refer to elders as stray dogs, which circulated in the streets without owners and collars and were captured by the 'cart.' Between 1973 and 2007, some Brazilian authorities made cars available to collect street animals (Motomura, 2018), but in 2008, this practice was legally prohibited. These memes, then, symbolically rescue the practice and transform it into something to demonstrate authority and to regulate the behavior of the elderly. It is noteworthy that memes bring illustrations, to some extent, aggressive, disguised in ironic humor to portray what society is entitled to do with the elderly during the pandemic. The surveillance in the text is similar to the one applied for minors, which contributes to portraying the elderly as fragile, vulnerable people (as in Lee et al., 2007; Rosenthal et al., 2021). It also suggests that the newly established dynamics of independence conquered by the elderly has dissipated (Debert, 2000).

\section{Theme 3: The elderly experience}

The third theme concerns the experience of the elderly themselves in the pandemic. Unlike other pieces, now the elderly's voice is made explicit. The text is a materialized personal record of how the elderly at stake behave in the face of the risk of contagion.

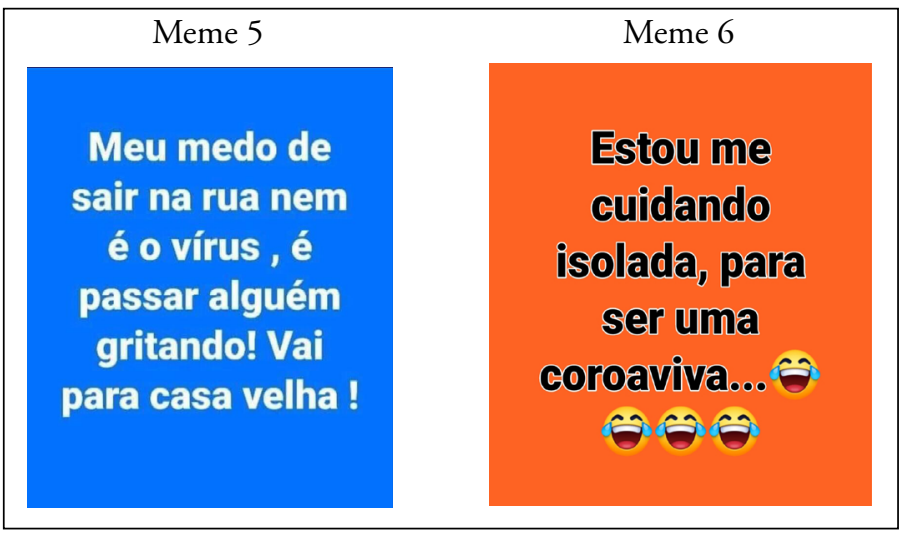

Figure 5. The elderly experience.

Source: Elaborated by the authors.

Meme 5 states: "My fear of going out has nothing to do with the virus, but with someone eventually yelling at me: 'Go home elder!'” Meme 6 shows some emojis laughing about the joke: "I am taking care of myself isolated, to be a 'coroaviva' [meaning an alive elder, playing on spelling coronavirus in Portuguese].” 
Both memes present an older woman as the narrator. In the first meme, the elderly is aware of society's vigilance over her. She is fearful of suffering social sanctions and dominance. In the second meme, she expresses her desire to stay alive, even in a scenario where death is a central element. She presents herself as someone independent, autonomous, and able to take care of herself. We observed that the memes use a kind of humor that is more empathic than derogatory.

The contrast and interaction of themes led to a global theme - authority under contest - that expresses an ideological perspective underpinning the production, consumption, and dissemination of memes during pandemics. In the next section, we describe the global theme in greater detail.

\section{Illustrating the global theme: Authority under contest}

The themes found in the memes reproduce the tension that involves aging in Brazil and the underlying meanings on how elderly should behave during the pandemic. Being elderly should correspond to being a master of oneself and have post-retirement projects, which contradicts their characterization in these cultural texts as a dependent person, under the control of the family and the state.

Pandemic memes about the elderly refer to a noninstitutionalized covert ideology, which people do not dare to confess feeling or thinking. Even if the elderly supports the house or are independent, the family and society still see them as someone who needs to be watched or controlled.
Unlike other cultural texts studied (Campos, 2009; Faria \& Casotti, 2014; Ramos et al., 2020; Suarez et al., 2009), the ideology is not romanticized. It offers a catharsis platform for the internal conflicts of people. There is a powerful struggle between youth and old age in these texts.

The global theme of the authority under contest portrays the tensions of a value system that stems from peers, from the sides. It is not proclaimed by an institutional author such as a mass media channel or marketing discourse. It results from the symbolic struggles of individuals that dare to share digitally what they do not dare to say in person. This cultural text, the meme, shows an ideology that is not politically correct or unified. Memes refer to a disorganized narrative, emerging from collective conflicting symbolic readings of the world, which are among themselves under contest.

\section{FINAL DISCUSSION}

We explored memes as methodological sources to inquiry consumer culture proposing broad guidelines for their investigation. The research defends the potential of memes as a cultural text that can reveal widespread beliefs, ideologies, and values. The methodological procedures (Figure 6) had the model of discourse (Hirschman et al., 1998) and the thematic analysis (Braun \& Clarke, 2006) as main inspiration. Press data and literature offered support for our analysis of the elderly context. Meme's production, consumption, and dissemination are the practices that compose the intertextuality behind the attempt of describing elderly behavior during a pandemic (Figure 6).

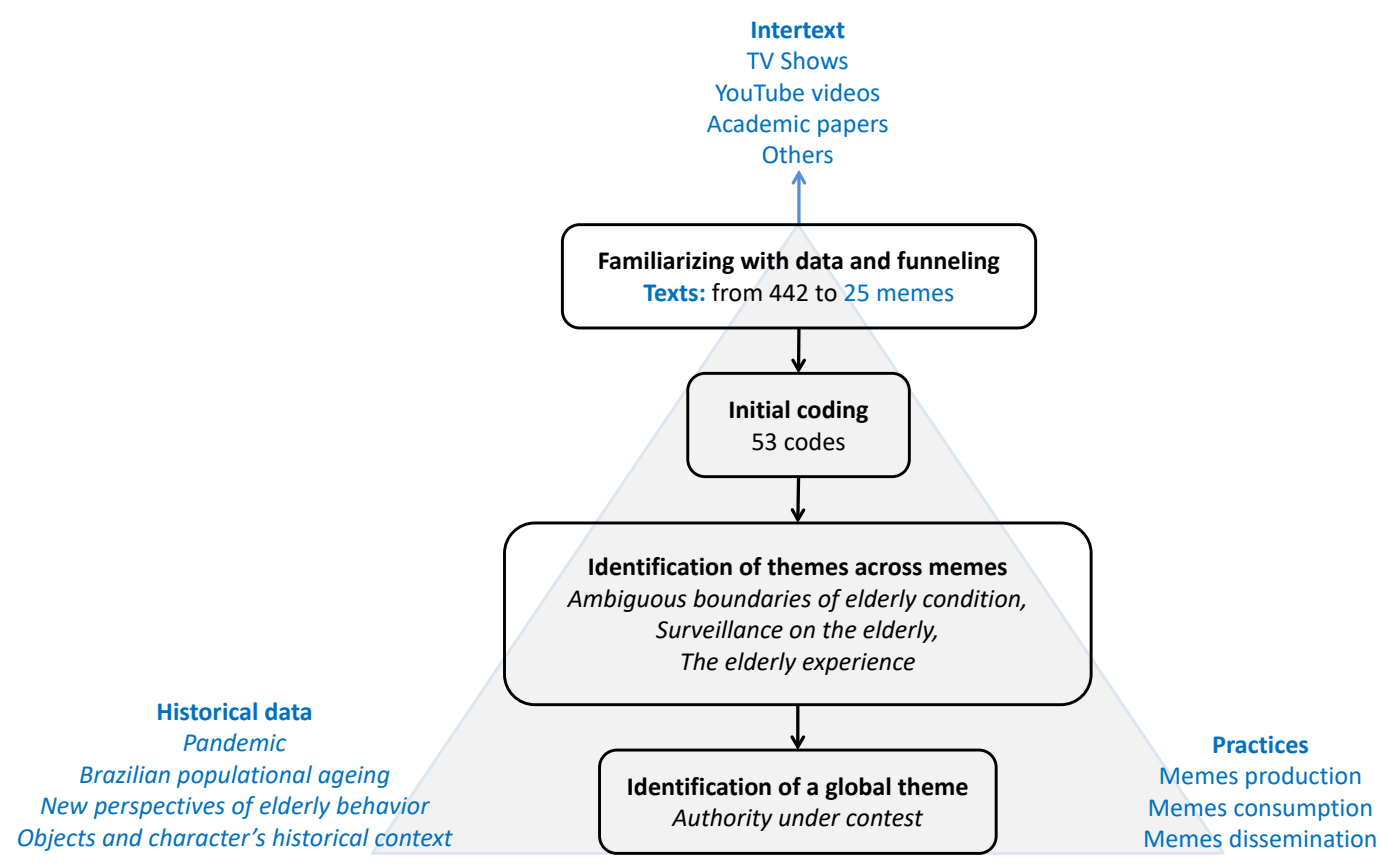

Figure 6. Memes as cultural text.

: Inspired by Hirschman et al. (1998). $\square$ : Inspired by Braun and Clarke (2006) and Lanka et al. (2020). Source: Elaborated
by the authors. 
Our contributions deploy into two main platforms. The first one refers to the outline of methodological procedures to use memes as a resource to research consumer culture, presenting data collection and data analysis protocols to instrumentalize future research with memes. Second, we contribute with the definition of the memes in the realm of research with cultural texts as an important tool to access covert collective ideologies.

We propose a methodological guideline to analyze memes following four stages. Data collection through outreaching diversified personal networks aims to compensate for the hard access to memes that circulate in closed networks such as WhatsApp. Familiarizing with data and funneling is the stage where we identify the final set of memes to be the basis of analytical procedures. Identification of themes was the next stage where memes were coded, and codes were then converted into themes. Finally, we identified a global theme that reveals ideological features that underpin the whole set of memes. These steps were illustrated with a real research project in the context of elderly consumers during COVID-19 pandemic.

Another contribution refers to the proposition of memes as a cultural text, which like others may provide access to circulating narratives in consumer culture. However, we have to point out the particular contributions that memes may offer. Memes are an organic cultural text, created by people to show a set of ideas, and manifest their internal conflicts, feelings, and opinions with humor. People also circulate memes they receive, to diffuse a message they identify with, or they want to actively disseminate. Unlike other cultural texts, ideologies present in memes do not have a

\section{REFERENCES}

Abreu, R. G., \& Casotti, L. M. (2018). Turismo na terceira idade sob a ótica da transformative consumer research. Revista Turismo em Análise, 29(2), 255-272. https://doi.org/10.11606/issn.1984-4867.v29i2p255-272

Abreu, R. G., \& Casotti, L. M. (2020). Viagens que transformam a condição existencial: Narrativas e representaçōes em filmes protagonizados por idosos. Revista Brasileira de Pesquisa em Turismo, 14(3), 14-31. https://doi.org/10.7784/rbtur.v14i3.1833

AdoroCinema (2020). Os Muppets. Retrieved from http://www.adorocinema.com/series/serie-782/

Anapol, A. (2020, August 06). Documenting a 'viral' pandemic: Why memes are the most apt way to communicate about Covid-19. PanMeMic. Retrieved from https://panmemic.hypotheses.org/737 central institutional authorship (Humphreys, 2010). Memes are anonymous pieces that are collectively and chaotically produced and circulated. They do not romanticize or openly advocate for a mainstream topic (Abreu \& Casotti, 2020; Campos, 2009; Holbrook, 2008), rather they represent the consumer's reception of mainstream ideologies converted into new ideologies, crafted with humor, cruelty, or honesty (Miller et al., 2020). They are politically incorrect and funny (Faria \& Casotti, 2014; Tadajewski \& Hamilton, 2014). They are the manifestation of marginal covert ideologies that circulate in the corridors of daily life and may even go against the institutionalized ideologies present in more institutionalized cultural texts. With social media, these counter-marginal-ideologies attain larger visibility. Thus, the analysis of memes offers an opportunity to contrast them to more institutionalized cultural texts and create a more complex account of circulating ideologies in consumer culture.

The limitation of the method lies in the characteristics of the meme itself. Memes spread quickly through social media, in the public or private domain. This research accesses them through consumers' networks. The advantage of analyzing memes from private sources is to watch what the particular groups are talking about or discussing. However, memes from private networks became a challenge and a limitation for the collection since it demands to overcome the barrier of personal access. Future projects may explore public sources of memes, such as a profile on social media that produces only memes. Another suggestion for future research may be to expand the analysis of memes as a cultural text using other contexts or to contrast it with more institutional cultural text forms.
Arnould, E. J., \& Thompson, C. J. (2005). Consumer culture theory (CCT): Twenty years of research. Journal of Consumer Research,31(4), 868-882. https://doi.org/10.1086/426626

Askegaard, S. (2010). Experience economy in the making: Hedonism, play and coolhunting in automotive song lyrics. Consumption, Markets and Culture, 13(4), 351-371. https://doi.org/10.1080/10253866.2010.502411

Blackmore, S. $\quad$ (2000). The power of memes.
$\begin{gathered}\text { Scientific } \\ \text { American, }\end{gathered}$ 283(4),
https://doi.org/10.1038/scientificamerican1000-64

Borgerson, J., \& Miller, D. (2016). Scalable sociality and "How the world changed social media": Conversation with Daniel Miller. Consumption Markets \& Culture, 19(6), 520-533. https://doi.org/10.1080/10253866.2015.1120980

Börzsei, L. K. (2013). Makes a meme instead: A concise history of internet memes. New Media Studies Magazine, 7(March). 
Braun, V., \& Clarke, V. (2006). Using thematic analysis in psychology. Qualitative Research in Psychology, 3(2), 77101.https://doi.org/10.1191/1478088706qp063oa

Brownlie, D., Hewer, P., \& Horne, S. (2005). Culinary tourism: An exploratory reading of contemporary representations of cooking. Consumption Markets \& Culture, 8(1), 7-26. https://doi.org/10.1080/10253860500068937

Brownlie, D., \&Hewer, P. (2007). Prime beefcuts: Culinaryimages for thinking 'men'. Consumption, Markets and Culture, 10(3), 229-250. https://doi.org/10.1080/10253860701365371

Campos, R. D. (2009). Be beautiful on the TV screen: Patterns of beauty and imagery in cultural television texts. Proceedings of Encontro Nacional da Associação Nacional de PósGraduação e Pesquisa em Administração, 33, São Paulo, SP, Brazil.

Cova, B., \& Cova, V. (2009). Faces of the new consumer: A genesis of consumer governmentality. Recherche et Applications en Marketing (English Edition), 24(3), 81-99. https://doi.org/10.1177/205157070902400304

Davison, P. (2009). The language of internet memes. In M. Mandiberg (Ed.), The social media reader (pp. 120-134). New York: NYU Press.

Dawkins, R. (1976). The selfish gene. New York: Oxford University Press.

Debert, G. G. (2000). O significado da velhice na sociedade brasileira. Acta Paulista de Enfermagem, 13(Spe1), 147158. Retrieved from https://acta-ape.org/en/article/osignificado-da-velhice-na-sociedade-brasileiral

Faria, M. D., \& Casotti, L. M. (2014). Representaçóes e estereótipos das pessoas com deficiência como consumidoras: O drama dos personagens com deficiência em telenovelas brasileiras. Organizaçōes \& Sociedade, 21(70), 387-404. https://doi.org/10.1590/S1984-92302014000300003

Freeman, L., \& Bell, S. (2013). Women's magazines as facilitators of Christmas rituals. Qualitative Market Research: An International Journal, 16(3), 336-354. https://doi.org/10.1108/13522751311326134

Gannon, V., \& Prothero, A. (2016). Beauty blogger selfies as authenticating practices. European Journal of Marketing, 50(9/10), 1858-1878. https://doi.org/10.1108/EJM-07-2015-0510

Goia, M. R., Lima, M. B., \& Barros, L. S. G. (2018). The deviation game: Can deviation from standard beauty become appealing? An age perspective. Revista Brasileira de Marketing, 17(4), 459-471. https://doi.org/10.5585/remark.v17i4.3754

Goldenberg, M. (2011). Corpo, envelhecimento e felicidade na cultura brasileira. Contemporânea (Título não-corrente), 9(2), 77-85. Retrieved from https://www.e-publicacoes. uerj.br/index.php/contemporanea/article/view/2143

GShow. (2020, August 06). Famosos resumem a quarentena e o ano de 2020 com montagem de fotos em desafio de memes na web. Gshow. Retrieved from https://gshow.globo.com/ Famosos/noticia/famosos-resumem-a-quarentena-e-oano-de-2020-com-montagem-de-fotos-em-desafio-dememes-na-internet.ghtml
Hirschman, E. C. (1988). The ideology of consumption: A structural-syntactical analysis of "Dallas" and "Dynasty". Journal of Consumer Research, 15(3), 344-359. https://doi.org/10.1086/209171

Hirschman, E. C. (2000). Consumers' use of intertextuality and archetypes. Advances in Consumer Research, 27, 57-63. Retrieved from https://www.acrwebsite.org/ volumes/8359/volumes/v27/NA-27

Hirschman, E. C., \& Stern, B. B. (1994). Women as commodities: Prostitution as depicted in the blue angel, pretty baby, and pretty woman. Advances in Consumer Research, 21, 576-581. Retrieved from https://www.acrwebsite.org/ volumes/5985/volumes/v21/NA-21

Hirschman, E. C., Scott, L., \& Wells, W. B. (1998). A model of product discourse: Linking consumer practice to cultural texts. Journal of Advertising, 27(1), 33-50. https://doi.org/10.1080/00913367.1998.10673541

Holbrook, M. B. (2008). Music meanings in movies: The case of the crime-plus-jazz genre. Consumption Markets \& Culture, 11(4), 307-327. https://doi.org/10.1080/10253860802391326

Holt, D. B. (2003). What becomes an icon most?. Harvard Business Review, 81(3), 43-49. Retrieved from https://hbr.org/2003/03/what-becomes-an-icon-most

Humphreys, A. (2010). Semiotic structure and the legitimation of consumption practices: The case of casino gambling. Journal of Consumer Research, 37(3), 490-510. https://doi.org/10.1086/652464

Humphreys, A., \& Latour, K. A. (2013). Framing the game: Assessing the impact of cultural representations on consumer perceptions of legitimacy. Journal of Consumer Research, 40(4), 773-795. https://doi.org/10.1086/672358

Lanier, C. D., Jr., Rader, C. S., \& Fowler, A. R., III. (2013). Anthropomorphism, marketing relationships, and consumption worth in the Toy Story trilogy. Journal of Marketing Management, 29(1-2), 26-47. https://doi.org/10.1080/0267257X.2013.769020

Lanka, E., Topakas, A., \& Patterson, M. (2020). Becoming a leader: Catalysts and barriers to leader identity construction. European Journal of Work and Organizational Psychology, 29(3), 377-390. https://doi.org/10.1080/1359432X.2019.1706488

Lee, M. M., Carpenter, B., \& Meyers, L. S. (2007). Representations of older adults in television advertisements. Journal of Aging Studies, 21(1), 23-30. https://doi.org/10.1016/j.jaging.2006.04.001

Luedicke, M. K., Thompson, C. J., \& Giesler, M. (2010). Consumer identity work as moral protagonism: How myth and ideology animate a brand-mediated moral conflict. Journal of Consumer Research, 36(6), 1016-1032. https://doi.org/10.1086/644761

Malhotra, N. K., Hall, J., Shaw, M., \& Oppenheim, P. P. (2008). Essentials of marketing research: An applied orientation (2 ed.). Frenchs Forest, NSW: Pearson Education Australia. 
McDonald,T., \& Dan, L. (2020). “Pulling the sheep'swool”: Thelabor of online thrift in a Chinese factory. Journal of Consumer Culture. https://doi.org/10.1177/1469540520955206

Miller, D. (2020, April 24). Memes - the moral police of the internet in the time of Covid-19. Anthrocovid. Retrieved from https://anthrocovid.com/2020/04/24/memes-themoral-police-of-the-internet-in-the-time-of-covid-19/

Miller, D., Costa, E., Haynes, N., McDonald, T., Nicolescu, R., Sinanan, J., Spyer, J., Venkatraman, S., \& Wang, X. (2020). How the world changed social media. London: UCL Press.

Miller, D., Costa, E., Haynes, N., McDonald, T., Nicolescu, R., Sinanan, J., Spyer, J., Venkatraman, S., \& Wang, X. (2019). Como o mundo mudou as mídias sociais. London: UCL Press.

Motomura, M. (2018, July 04). Cães apanhados na rua realmente viram sabão? SuperInteressante. Retrieved from https:// super.abril.com.br/mundo-estranho/caes-apanhados-narua-realmente-viram-sabao/

Neri, M. (2020). Onde estão os idosos? Conhecimento contra o COVID-19. Retrieved from https://cps.fgv.br/covidage

Perissé, C., \& Marli, M. (2019, March 19). Idosos indicam caminhos para uma melhor idade. Agência de Notícias. Retrieved from https://agenciadenoticias.ibge. gov.br/agencia-noticias/2012-agencia-de-noticias/ noticias/24036-idosos-indicam-caminhos-para-umamelhor-idade\#:- :text=O\%20Brasil\%20tem $\% 20$ mais $\% 20$ de, divulgada $\% 20 \mathrm{em} \% 202018 \% 20$ pelo\%20IBGE
Ramos, R. C., Tayt-Son, D. B. C., \& Rocha, A. R. C. (2020). A volta da marmita: Ressignificação do consumo à luz da teoria da prática. Proceedings of the Encontro Nacional da Associação Nacional de Pós-Graduação e Pesquisa em Administração, 44, Online.

Reis, D., Jr. (2013). Objetos do baú: Ficha telefônica. Retrieved from https://www.propagandashistoricas.com.br/2013/06/ objetos-do-bau-ficha-telefonica.html

Rodrigues, L. R., \& Soares, G. A. (2006). Velho, idoso e terceira idade na sociedade contemporânea. Revista Ágora, (4). Retrieved from https://periodicos.ufes.br/agora/article/view/1901

Rosenthal, B., Cardoso, F., \& Abdalla, C. (2021). (Mis) representations of older consumers in advertising: Stigma and inadequacy in ageing societies. Journal of Marketing Management, 37(5-6), 569-593. https://doi.org/10.1080/0267257X.2020.1850511

Saldaña, J. (2009). The coding manual for qualitative researchers. Thousand Oaks: Sage.

Suarez, M., Motta, P. C., \& Barros, C. (2009). Consumo e castigo: Um retrato das relaçóes de consumo no seriado A Diarista. In A. Rocha \& J. F. Silva (Orgs.), Consumo na base da pirâmide: Estudos Brasileiros. Rio de Janeiro: Mauad X.

Tadajewski, M., \& Hamilton, K. (2014). Waste, art, and social change: Transformative consumer research outside of the academy?. Journal of Macromarketing, 34(1), 80-86. https://doi.org/10.1177/0276146713509631

Thompson, C. J. (2004). Marketplace mythology and discourses of power. Journal of Consumer Research, 31(1), 162-180. https://doi.org/10.1086/383432 


\section{Authorship}

\section{Elisa Priori de Deus*}

Universidade Federal do Rio de Janeiro, Instituto COPPEAD de Administração

Rua Pascoal Lemme, n. 355, Cidade Universitária, 21941-616, Rio de Janeiro, RJ, Brazil

E-mail: elisa.priori@coppead.ufrj.br

(D) https://orcid.org/0000-0002-1719-3959

\section{Roberta Dias Campos}

Universidade Federal do Rio de Janeiro, Instituto COPPEAD de Administração

Rua Pascoal Lemme, n. 355, Cidade Universitária, 21941-616, Rio de Janeiro, RJ, Brazil

E-mail: roberta.campos@coppead.ufrj.br

(D) https://orcid.org/0000-0002-7091-7901

\section{Ana Raquel Rocha}

Universidade Federal do Rio de Janeiro, Instituto COPPEAD de Administração

Rua Pascoal Lemme, n. 355, Cidade Universitária, 21941-616, Rio de Janeiro, RJ, Brazil

E-mail: anaraquelcr@hotmail.com

(D) https://orcid.org/0000-0002-0478-5146

* Corresponding Author

\section{Conflict of Interests}

The authors have stated that there is no conflict of interest.

\section{Copyrights}

RAC owns the copyright to this content.

\section{Funding}

The authors reported that there is no financial support for the research in this article.

\section{Plagiarism Check}

The RAC maintains the practice of submitting all documents approved for publication to the plagiarism check, using specific tools, e.g.: iThenticate.

\section{Authors' Contributions}

$1^{\text {st }}$ author: conceptualization (equal); data curation (lead); formal analysis (lead); investigation (equal); methodology (equal); project administration (equal); supervision (equal); validation (equal); visualization (equal); writing - original draft (lead); writing - review \& editing (equal).

$2^{\text {nd }}$ author: conceptualization (equal); data curation (equal); formal analysis (equal); investigation (equal); methodology (equal); project administration (equal); supervision (lead); validation (equal); visualization (equal); writing - original draft (equal); writing - review \& editing (equal).

$3^{\text {rd }}$ author: conceptualization (equal); data curation (equal); formal analysis (equal); investigation (equal); methodology (equal); project administration (equal); supervision (equal); validation (equal); visualization (equal); writing - original draft (equal); writing - review \& editing (lead).

\section{Peer Review Method}

This content was evaluated using the double-blind peer review process. The disclosure of the reviewers' information on the first page, as well as the Peer Review Report, is made only after concluding the evaluation process, and with the voluntary consent of the respective reviewers and authors.

\section{Data Availability}

The author claim that all data and materials have been made publicly available through the Harvard Dataverse platform and can be accessed at:

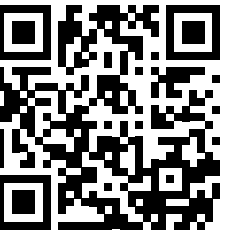

Deus, Elisa Priori de; Campos, Roberta Dias; Rocha, Ana Raquel, 2021, "Replication Data for: "Memes as shortcut to consumer culture: a methodological approach undercovered collective ideologies" published by RAC. Revista de Administração Contemporânea", Harvard Dataverse, V1. https://doi.org/10.7910/DVN/25VIFD

RAC encourages data sharing but, in compliance with ethical principles, it does not demand the disclosure of any means of identifying research subjects, preserving the privacy of research subjects. The practice of open data is to enable the reproducibility of results, and to ensure the unrestricted transparency of the results of the published research, without requiring the identity of research subjects. 